\title{
Description of Azospira restricta sp. nov., a nitrogen-fixing bacterium isolated from groundwater
}

\author{
Hee-Sung Bae, ${ }^{1}$ Brian A. Rash, ${ }^{1}$ Fred A. Rainey, ${ }^{1}$ M. Fernanda Nobre, ${ }^{2}$ \\ Igor Tiago, ${ }^{2}$ Milton S. da Costa ${ }^{3}$ and William M. Moe ${ }^{4}$
${ }^{1}$ Department of Biological Sciences, Louisiana State University, Baton Rouge, LA 70803, USA
${ }^{2}$ Departamento de Zoologia and Centro de Neurociências, Universidade de Coimbra, 3004-517 Coimbra, Portugal
${ }^{3}$ Departamento de Bioquímica and Centro de Neurociências, Universidade de Coimbra, 3001-401 Coimbra, Portugal
${ }^{4}$ Department of Civil and Environmental Engineering, Louisiana State University, Baton Rouge, LA 70803, USA

Correspondence

William M. Moe

moemwil@lsu.edu

\begin{abstract}
A novel, Gram-negative bacterial strain, $S U A 2^{\top}$, isolated from groundwater, was characterized using a polyphasic approach. Cells are Gram-negative, non-spore-forming, straight to curved rods with a single polar flagellum. Strain SUA2 ${ }^{\top}$ is oxidase- and catalase-positive and is able to fix nitrogen. Poly- $\beta$-hydroxybutyrate storage granules are produced. Dominant fatty acids when grown in R2A and VM ethanol media for $72 \mathrm{~h}$ at $37^{\circ} \mathrm{C}$ are $\mathrm{C}_{16: 0}, \mathrm{C}_{16: 1} \omega 7 \mathrm{c}, \mathrm{C}_{17: 0}$ cyclo, $\mathrm{C}_{10: 0} 3-\mathrm{OH}$, $\mathrm{C}_{18: 1} \omega 7 \mathrm{c}, \mathrm{C}_{12: 0}$ and $\mathrm{C}_{15: 0}$. DNA $\mathrm{G}+\mathrm{C}$ content is 67.9 mol\%. Phenotypic and phylogenetic data indicate that strain SUA $2^{\top}$ is related to, but clearly differentiated from Azospira oryzae. Strain SUA2 ${ }^{\top}$ is thus proposed as a novel species of the genus Azospira with the name Azospira restricta sp. nov. The description of the genus Azospira is emended to include the characteristics of this novel species. The type strain of Azospira restricta is SUA2 ${ }^{\top}$ ( $=$ NRRL B-41660 ${ }^{\top}=\mathrm{DSM}$ $18626^{\top}=$ LMG $23819^{\top}$ ).
\end{abstract}

The genus Azospira was described by Reinhold-Hurek \& Hurek (2000) to accommodate a lineage of nitrogen-fixing bacteria within the Betaproteobacteria that could be phylogenetically and phenotypically differentiated from other strains originally assigned to the genus Azoarcus sensu lato (Reinhold-Hurek et al., 1993). At present, the genus Azospira includes a single validly published species, Azospira oryzae, strains of which have been isolated from surface-sterilized roots of gramineae such as Kallar grass (Leptochloa fusca) and rice (Oryza), or resting stages (sclerotia) of a basidiomycete (Reinhold-Hurek \& Hurek, 2000). The description of Azospira oryzae sp. nov. was recently emended to accommodate perchlorate-reducing strains isolated from a swinewaste treatment lagoon that were originally described as Dechlorosoma suillum (Achenbach et al., 2001), but which were later shown to be phylogenetically and phenotypically

The GenBank/EMBL/DDBJ accession numbers for the 16S rRNA gene and nifH sequences of strain SUA2 ${ }^{\top}$ are D0974114 and EF158046, respectively.

Supplementary figures showing morphological features and whole-cell soluble protein patterns (SDS-PAGE), and a supplementary table of fatty acid composition data are available with the online version of this paper. similar to and represent a later subjective synonym of Azospira oryzae (Tan \& Reinhold-Hurek, 2003).

During a study aimed at characterizing the microbial population in groundwater from an uncontaminated groundwater well located upgradient from a hazardous waste site near Baton Rouge, Louisiana, USA (Bowman et al., 2006), a novel bacterial strain, designated $\mathrm{SUA} 2^{\mathrm{T}}$, was isolated on R2A agar (Difco) incubated aerobically at $23{ }^{\circ} \mathrm{C}$. Purity of the strain was verified by microscopy after multiple transfers.

Colony morphology was observed after aerobic growth on plates of VM ethanol medium (Reinhold-Hurek \& Hurek, 2000) incubated at $37^{\circ} \mathrm{C}$ for 4 days, or R2A (Difco) at $30^{\circ} \mathrm{C}$ for 7 days. Cell morphology was observed by phase-contrast microscopy (Nikon Optiphot), differential interference contrast microscopy (Nikon microphot-Fxa) and transmission electron microscopy (JEOL 1000CX TEM). Electron micrographs were taken from cells negatively stained with uranyl acetate $(2 \%, v / v)$. Gram staining and catalase tests were performed as described by Smibert \& Krieg (1981). Oxidase tests were performed as described by Tarrand \& Gröschel (1982). NaCl tolerance was tested in liquid VM 
ethanol medium supplemented with 1.0 and $2.0 \%(\mathrm{w} / \mathrm{v})$ $\mathrm{NaCl}$. The temperature range for growth was tested in liquid $\mathrm{VM}$ ethanol medium incubated at temperatures of 15,20 , 23, 30, 37 and $40^{\circ} \mathrm{C}$. Additional biochemical and physiological properties were determined using API $20 \mathrm{NE}$ (bioMérieux) test kits, according to the manufacturer's instructions. Substrate metabolism was determined on Biolog GN and GP MicroPlates inoculated with cells grown in R2A liquid broth overnight at $23^{\circ} \mathrm{C}$. Cells were washed with a $0.9 \%(\mathrm{w} / \mathrm{v}) \mathrm{NaCl}$ solution, centrifuged and resuspended in the inoculation fluid provided with the kit. Substrate metabolism was determined by purple colour development after incubation of the plate at $30{ }^{\circ} \mathrm{C}$ for $85 \mathrm{~h}$ followed by measurement of $A_{595}$ using an automated plate reader (Multiskan Ascent, version 4.0; Labsystems).

The ability of SUA2 ${ }^{\mathrm{T}}$ cells to use nitrate or perchlorate as alternative electron acceptors was tested using anoxic DSMZ medium 908 (www.dsmz.de/media/med908.htm) with acetate replaced by lactate $(10 \mathrm{mM})$ and supplemented with either sodium nitrate $(10 \mathrm{mM})$ or sodium perchlorate $(10 \mathrm{mM})$ as potential electron acceptors. For both perchlorate and nitrate, electron acceptor utilization was assessed by comparing growth of cells in the perchlorate- or nitratecontaining medium with control cultures prepared in media without the supplemental electron acceptor after 8 days incubation at $30^{\circ} \mathrm{C}$. Nitrate reduction and denitrification activities were further assessed as described by Smibert \& Krieg (1981).

Nitrogen-fixing ability was determined by growth and acetylene reduction in semi-solid $(0.2 \% \mathrm{w} / \mathrm{v}$, agar $)$, nitrogen-free SM medium (Reinhold et al., 1986), in which malate was replaced by $10 \mathrm{mM}$ lactate. Cells grown on R2A for 3 days were inoculated vertically into $17 \mathrm{ml}$ Hungate tubes containing $10 \mathrm{ml}$ of the semi-solid SM medium using a sterile loop. The headspace was supplemented with $0.2 \mathrm{ml}$ acetylene prior to incubation at $30^{\circ} \mathrm{C}$ for 8 days. Uninoculated tubes served as negative controls. Acetylene reduction (ethylene production) was determined by analysis of $0.1 \mathrm{ml}$ gas headspace samples using a gas chromatograph (HP6890; HP) equipped with a capillary column (GS-Gaspro, $60 \mathrm{~m} \times 0.32 \mathrm{~mm}$ i.d.; J\&W P/N 1134362 ) and a flame-ionization detector. Helium was used as carrier gas at a flow rate of $45 \mathrm{ml} \mathrm{min}{ }^{-1}$. The injector and detector temperature was $225^{\circ} \mathrm{C}$. The oven temperature was increased from 50 to $200^{\circ} \mathrm{C}$ at a rate of $50^{\circ} \mathrm{C} \mathrm{min}^{-1}$. A PCRbased assay using the PolF/PolR PCR primer set and a PCR protocol as described by Poly et al. (2001) was used to detect presence of the nifH gene.

For the preparation of soluble whole-cell proteins, cells were cultured in liquid R2A medium overnight and washed with $20 \mathrm{mM}$ potassium phosphate buffer ( $\mathrm{pH}$ 7.0). Cells were disrupted by sonication (Fisher Scientific Sonic Dismemberator) at $20 \mathrm{kHz}$ in an ice bath. After removal of cell debris by centrifugation at $16000 \mathrm{~g}$ for $15 \mathrm{~min}$, soluble proteins were separated by SDS-PAGE on a $12.5 \%(\mathrm{w} / \mathrm{v})$ polyacrylamide gel (30:1, w/w, acrylamide/bisacrylamide).
Protein bands were visualized by staining with Coomassie brilliant blue R250. For comparison purposes, Azospira oryzae strains $6 \mathrm{a} 3^{\mathrm{T}}$ ( = LMG $9096^{\mathrm{T}}$ ), obtained from BCCM/ LMG (the Belgian Co-ordinated Collections of Microorganisms/Laboratorium voor Microbiologie) and PS (syn. Dechlorosoma suillum), kindly provided by Dr John Coates of the University of California at Berkeley, were also analysed. These two reference strains were grown and processed in exactly the same manner as strain $\mathrm{SUA}^{\mathrm{T}}$.

Cellular fatty acids were extracted, saponified and methylated according to the protocol of the Sherlock Microbial Identification System (MIDI) after growth in R2A (this study) and VM ethanol (DSMZ Identification Service) media for $72 \mathrm{~h}$ at $37^{\circ} \mathrm{C}$. The fatty acids were analysed by a gas chromatograph equipped with the Microbial Identification software package (Sasser, 1990). Genomic DNA G + C content was determined by HPLC as described by Mesbah et al. (1989).

Poly- $\beta$-hydroxybutyrate (PHB) extraction, collection and conversion to crotonic acid were performed according to the protocol of Smibert \& Krieg (1981). Strain SUA2 ${ }^{\mathrm{T}}$ and Azospira oryzae strains $6 \mathrm{a} 3^{\mathrm{T}}$ and PS were grown in liquid R2A medium for 5 days at $30^{\circ} \mathrm{C}$ on a rotary shaker prior to biomass collection for this analysis. The presence of crotonic acid was detected spectrophotometrically at 235 nm (Smibert \& Krieg, 1981).

Extraction of genomic DNA, PCR amplification and sequencing of 16 rRNA genes was carried out as described by Rainey et al. (1996). Purified sequencing-reaction products were electrophoresed using a model 3100 DNA sequencer (Applied Biosystems). The 16S rRNA gene sequence of strain $\mathrm{SUA}_{2}{ }^{\mathrm{T}}$ was aligned against previously determined sequences from the NCBI database (www. ncbi.nlm.nih.gov) using the BioEdit (version 4.7.8; Hall, 1999) and CLUSTAL_X programs (Thompson et al., 1997). Phylogenic analyses were performed using components of the MEGA 3.1 package (Kumar et al., 2004). The neighbourjoining algorithm was used to build the phylogenetic tree from distance matrices calculated with Jukes-Cantor correction (Jukes \& Cantor, 1969). Bootstrap analysis was performed using PHYLIP 3.62 (Felsenstein, 2004; http:// evolution.genetics.washington.edu/phylip.html) with 1000 resamplings.

The characteristics of strain $\mathrm{SUA} 2^{\mathrm{T}}$ are provided in the emended genus and species description (Table 1, and Supplementary Fig. S1, available with the online version of this paper). Strain $S U A 2^{T}$ grew in semi-solid, nitrogenfree medium, forming pellicles that moved up to the surface, indicating that strain $\mathrm{SUA2}^{\mathrm{T}}$ was able to fix $\mathrm{N}_{2}$ gas as a nitrogen source. After 8 days incubation in nitrogen-free medium, reduction of acetylene $\left(\mathrm{C}_{2} \mathrm{H}_{2}\right)$ to ethylene $\left(\mathrm{C}_{2} \mathrm{H}_{4}\right)$ was observed via GC, further indicating that strain $\mathrm{SUA}^{\mathrm{T}}$ exhibits nitrogenase activity. The presence of the nifH gene was detected by gel electrophoresis following PCR amplification using the PolF/PolR PCR primer set described by 
Table 1. Characteristics of strain SUA2 ${ }^{\top}$ and Azospira oryzae

Data for Azospira oryzae were taken from Reinhold-Hurek \& Hurek (2000) and Tan \& Reinhold-Hurek (2003), except for fatty acid data which were determined in the present study using methods and growth conditions identical to those used for strain SUA2 ${ }^{\mathrm{T}}$. All are Gram-negative, non-spore-forming, straight to curved rods with a single polar flagellum, oxidase- and catalase-positive, and able to fix nitrogen. All are unable to grow in the presence of $2 \% \mathrm{NaCl}(\mathrm{w} / \mathrm{v})$. All utilize $\beta$-hydroxybutyric acid and D,L-lactic acid, but do not utilize $N$-acetyl-D-glucosamine, adonitol, L-alanine, $\gamma$-aminobutyric acid, L-arabinose, D-arabitol, D-cellobiose, erythritol, D-fructose, L-fucose, D-galactose, D-galacturonic acid, gentiobiose, D-gluconic acid, D-glucose, $\gamma$-hydroxybutyric acid, $m$-inositol, $\alpha$-ketoglutaric acid, D-lactose, lactulose, D-maltose, D-mannose, D-melibiose, L-phenylalanine, L-proline, D-raffinose, L-rhamnose, Dribose, D-sorbitol, sucrose, D-tagatose, D-trehalose, turanose, xylitol or D-xylose.

\begin{tabular}{|c|c|c|c|}
\hline Characteristic & SUA2 $^{\mathrm{T}}$ & $\begin{array}{c}\text { Azospira oryzae } 63^{\mathrm{T}} \\
\quad\left(=\mathrm{LMG} 9096^{\mathrm{T}}\right)\end{array}$ & $\begin{array}{c}\text { Azospira oryzae PS } \\
\left(=\text { DSM } 13638^{\mathrm{T}}\right)\end{array}$ \\
\hline Origin & Groundwater & Kallar grass & $\begin{array}{l}\text { Swine-waste } \\
\text { treatment lagoon }\end{array}$ \\
\hline Cell dimension $(\mu \mathrm{m})$ & $0.5 \times 1.2-2.5$ & $0.4-0.6 \times 1.1-2.5$ & $0.3 \times 1.0$ \\
\hline $\begin{array}{l}\text { Colony colour on VM ethanol } \\
\text { medium }\end{array}$ & Greenish-yellow & Orange & Orange \\
\hline Nitrate reduction & - & + & + \\
\hline Perchlorate utilization & - & - & + \\
\hline DNA $\mathrm{G}+\mathrm{C}$ content $(\mathrm{mol} \%)$ & 67.9 & 65.2 & 65.8 \\
\hline \multicolumn{4}{|l|}{ Fatty acids (\%) } \\
\hline $\mathrm{C}_{8: 0} 3-\mathrm{OH}$ & - & 1.6 & 0.9 \\
\hline $\mathrm{C}_{10: 0}$ & 0.6 & - & - \\
\hline $\mathrm{C}_{10: 0} 3-\mathrm{OH}$ & 6.5 & - & 0.1 \\
\hline $\mathrm{C}_{12: 0}$ & 3.8 & - & - \\
\hline $\mathrm{C}_{14: 0}$ & 1.2 & 0.6 & 0.8 \\
\hline $\mathrm{C}_{15: 0}$ & 2.4 & 0.4 & 0.6 \\
\hline $\mathrm{C}_{16: 1} \omega 7 \mathrm{c}$ & 32.0 & 43.6 & 41.8 \\
\hline $\mathrm{C}_{16: 0}$ & 37.4 & 43.9 & 48.5 \\
\hline $\mathrm{C}_{17: 1} \omega 8 \mathrm{c}$ & 0.4 & 0.1 & 0.1 \\
\hline $\mathrm{C}_{17: 0}$ cyclo & 6.6 & - & - \\
\hline $\mathrm{C}_{17: 0}$ & 0.6 & 0.3 & 0.4 \\
\hline $\mathrm{C}_{18: 1} \omega 7 \mathrm{c}$ & 6.2 & 8.3 & 5.4 \\
\hline $\mathrm{C}_{18: 0}$ & 0.6 & 0.6 & 0.5 \\
\hline \multicolumn{4}{|l|}{ Utilization of: } \\
\hline Acetic acid & - & + & + \\
\hline$\alpha$-Ketoglutaric acid & - & + & + \\
\hline Propionic acid & - & + & + \\
\hline Succinic acid & - & + & + \\
\hline L-Aspartic acid & - & + & + \\
\hline L-Glutamic acid & - & + & + \\
\hline L-Malic acid & - & + & + \\
\hline Putrescine & + & - & - \\
\hline$\gamma$-Hydroxybutyric acid & + & - & - \\
\hline
\end{tabular}

Poly et al. (2001). The gene sequence was verified by sequencing of the PCR product.

Comparison of the fatty acid composition of strain SUA2 ${ }^{\mathrm{T}}$ with that described for Azospira oryzae strain $63^{\mathrm{T}}$ in the description of the genus Azospira (Reinhold-Hurek \& Hurek, 2000) showed large differences in the major fatty acids detected. In the description of the genus Azospira, which was based on Azospira oryzae $63^{\mathrm{T}}$, the major fatty acids were described as $\mathrm{C}_{10: 1} 3-\mathrm{OH}, \mathrm{C}_{16: 0}, \mathrm{C}_{16: 1} \omega 9 \mathrm{c}$ and $\mathrm{C}_{18: 0}$. However, reanalysis of the fatty acids of strains $6 \mathrm{a} 3^{\mathrm{T}}\left(=\mathrm{LMG} 9069^{\mathrm{T}}\right)$ and PS showed that three of the four fatty acids, namely $\mathrm{C}_{10: 1} 3-\mathrm{OH}, \mathrm{C}_{16: 1} \omega 9 \mathrm{c}$ and $\mathrm{C}_{18: 0}$, described as major fatty acids in the description of the genus Azospira (Reinhold-Hurek \& Hurek, 2000) are in fact not detected in the Azospira oryzae strains (Table 1). These data were reanalysed in two independent laboratories after the cells had been grown on VM ethanol medium under the 


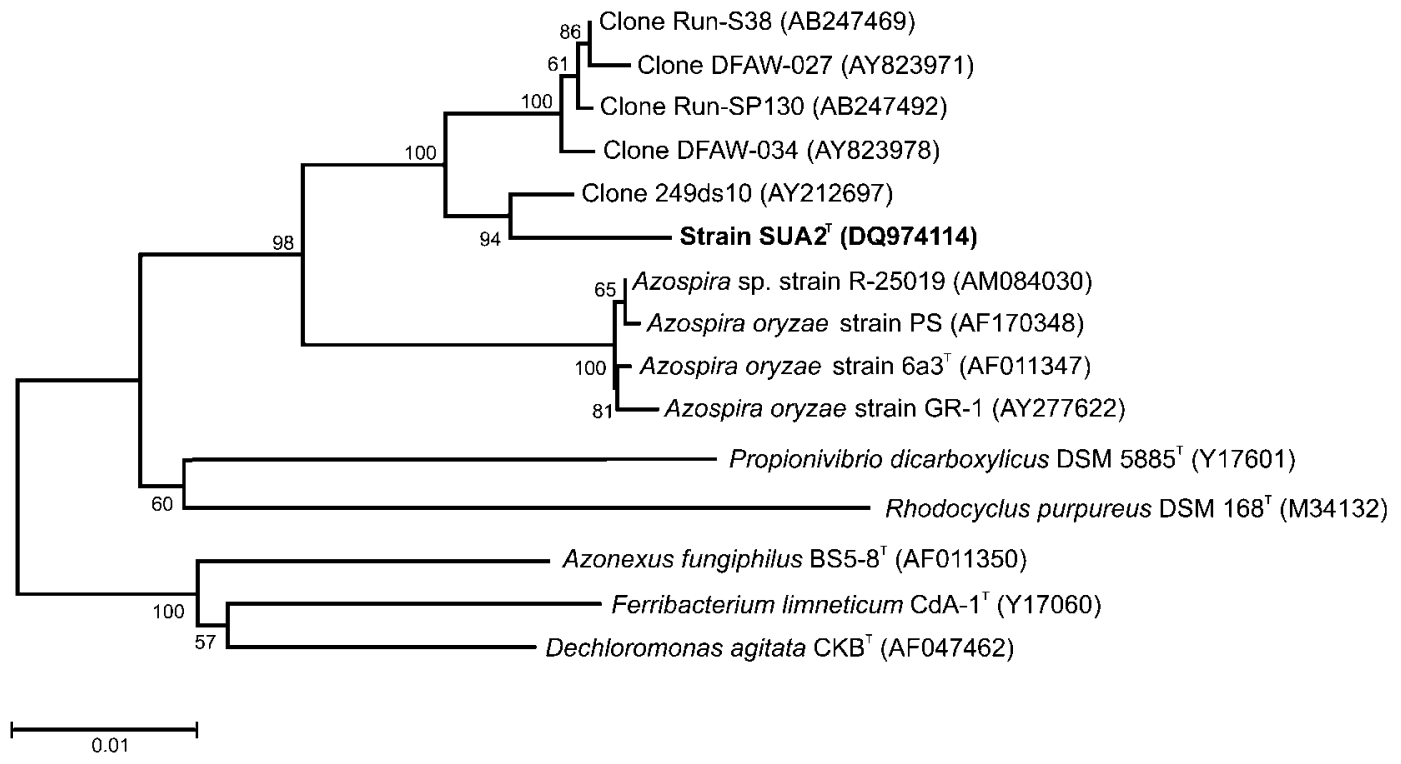

Fig. 1. Neighbour-joining tree showing the phylogenetic relationship of $S U A 2^{\top}$, related taxa and environmental clone sequences on 16S rRNA gene sequences. Bootstrap values expressed as a percentage of 1000 replications are shown at the branching points. Bar, 1 inferred nt substitution per $100 \mathrm{nt}$.

conditions described by Reinhold-Hurek \& Hurek (2000) and also on R2A medium (Supplementary Table S1, available with the online version of this paper).

Nearly complete 16S rRNA gene sequences were used to reconstruct a phylogenetic dendrogram showing the relationship between strain SUA2 ${ }^{\mathrm{T}}$, Azospira oryzae strains, other genera in the family Rhodocyclaceae and environmental 16S rRNA gene sequences (Fig. 1). Sequence similarity between strain $\mathrm{SUA} 2^{\mathrm{T}}$ and the closest relative for which a sequence is available from the public databases, the uncultured groundwater bacterium 249ds10 (AY212697; Simpson et al., 2004), was $98.1 \%$. 16S rRNA gene sequence similarities between strain $\mathrm{SUA} 2^{\mathrm{T}}$ and the four closest cultured relatives, Azospira oryzae strains 6a ${ }^{\mathrm{T}}$, PS, GR-1 and R-25019 (AF011347, AF170348, AY277622 and AM084030, respectively), were in the range $95.7-95.8 \%$, indicating that strain $\mathrm{SUA} 2^{\mathrm{T}}$ represents a distinct, but related lineage to this species. High bootstrap values support the novelty of the lineage represented by strain SUA2 ${ }^{\mathrm{T}}$. Strain $\mathrm{SUA}^{\mathrm{T}}$ is the first cultured member of this lineage which is currently composed of environmental 16S rRNA gene sequences from groundwater and activated sludge samples. The $16 \mathrm{~S}$ rRNA gene sequence of strain $\mathrm{SUA} 2^{\mathrm{T}}$ shares between 97.1 and $98.1 \%$ similarity with the sequences of these as yet uncultured organisms. The clear differentiation of strain SUA2 ${ }^{\mathrm{T}}$ from Azospira oryzae at the gene level was also seen in the comparison of the partial nifH gene sequence which showed only $81.5 \%$ nucleotide similarity over 269 positions compared to those of Azospira oryzae strains $63^{\mathrm{T}}$ and PS. The highest similarity between the nifH gene sequence of strain $\mathrm{SUA}^{\mathrm{T}}$ was to that of the unrelated taxon Azonexus caeni
(DQ029203) at $94 \%$. The DNA G + C content of strain $\mathrm{SUA2}^{\mathrm{T}}$ was $67.9 \mathrm{~mol} \%$.

To further investigate differences between strain $\mathrm{SUA} 2^{\mathrm{T}}$ and the related Azospira oryzae strains, whole cell soluble proteins were compared by SDS-PAGE (Supplementary Fig. S2, available with the online version of this paper). The protein patterns of Azospira oryzae strains $6 \mathrm{a}^{\mathrm{T}}$ and PS were quite similar to one another, whereas the protein pattern of strain SUA2 ${ }^{\mathrm{T}}$ was clearly different. Strain SUA2 ${ }^{\mathrm{T}}$ and Azospira oryzae strain $6 \mathrm{a} 3^{\mathrm{T}}$ all produced polyhydroxybutyrate when grown in liquid R2A medium for 5 days at $30^{\circ} \mathrm{C}$.

Morphological characteristics and some phenotypic properties of strain SUA2 ${ }^{\mathrm{T}}$ confer with those described for the genus Azospira (Reinhold-Hurek \& Hurek, 2000). These phenotypic features include the Gram-negative reaction, heterotrophic metabolism, non-spore-forming, curved rods with cells ranging from 0.4 to $0.6 \mu \mathrm{m}$ in width and from 1.1 to $2.5 \mu \mathrm{m}$ in length, motility by means of a single polar flagellum, production of catalase and oxidase, ability to grow well at $37^{\circ} \mathrm{C}$, absence of growth in the presence of $2 \%(\mathrm{w} / \mathrm{v}) \mathrm{NaCl}$, capacity for nitrogen $\left(\mathrm{N}_{2}\right)$ fixation and reduction of acetylene to ethylene. Strain $\mathrm{SUA}^{\mathrm{T}}$ also matches the phenotypic feature of the Azospira genus description in that no growth occurs on mono- or disaccharides, nor on most amino acids.

However, some of the phenotypic characteristics determined for strain $\mathrm{SUA}^{\mathrm{T}}$ do not confer with the current description of the genus Azospira. Specifically, strain SUA2 ${ }^{\mathrm{T}}$ is unable to utilize nitrate as a terminal electron acceptor and does not grow on organic acids such as L-malate, succinate, 
fumarate, acetate, 2-oxoglutarate, $n$-caproate and propionate, nor on ethanol. In addition, the $\mathrm{G}+\mathrm{C}$ content of genomic DNA from strain SUA2 ${ }^{\mathrm{T}}, 67.9 \mathrm{~mol} \%$, is outside of the range of $65-66 \mathrm{~mol} \%$ for the genus.

Strain SUA2 ${ }^{\mathrm{T}}$ is clearly discriminated from Azospira oryzae, the only validly published species of the genus Azospira, by substrate utilization, inability to utilize nitrate or perchlorate as electron acceptors and colony colour when grown on VM ethanol medium (Table 1). Fatty acid composition also distinguishes strain SUA2 ${ }^{\mathrm{T}}$ from Azospira oryzae strains, based on the presence of $\mathrm{C}_{17: 0}$ cyclo, $\mathrm{C}_{10: 0} 3-\mathrm{OH}, \mathrm{C}_{12: 0}$ and $\mathrm{C}_{10: 0}$ in the former and absence or presence of only trace quantities in the latter when grown at $37^{\circ} \mathrm{C}$ on $\mathrm{R} 2 \mathrm{~A}$ medium. Whole-cell soluble protein patterns analysed by SDS-PAGE (supplementary Fig. S1) demonstrated that strain $\mathrm{SUA}_{2}{ }^{\mathrm{T}}$ is distinct from Azospira oryzae in overall protein profiles, and nifH gene sequences also differ, supporting the classification of strain SUA2 ${ }^{\mathrm{T}}$ as a novel species.

On the basis of phylogenetic, chemotaxonomic and phenotypic features obtained in this study, strain SUA2 ${ }^{\mathrm{T}}$ is clearly discriminated from the one validly published species of the genus Azospira. Considering the lack of genus-level characteristics for differentiation of strain SUA2 ${ }^{\mathrm{T}}$ from Azospira oryzae as well as the relatively high $16 \mathrm{~S}$ rRNA gene sequence similarities, we propose strain $\mathrm{SUA} 2^{\mathrm{T}}$ as a novel species which we have named Azospira restricta sp. nov. In addition, we have emended the genus description for Azospira to include the characteristics of this novel species and to clarify the fatty acid content.

\section{Emended description of the genus Azospira Reinhold-Hurek \& Hurek 2000; Tan \& Reinhold-Hurek 2003}

The emended description is based on the results of Reinhold-Hurek \& Hurek (2000), Tan \& Reinhold-Hurek (2003) and this study. Gram-negative, non-spore-forming, curved rods. Motile by means of a single polar flagellum. Aerobic, capable of microaerophilic growth in semi-solid, $\mathrm{N}$-free media. Variable with respect to use of nitrate and perchlorate as terminal electron acceptors. Heterotrophic. Oxidase-positive. Catalase-positive. Capable of nitrogen fixation. Growth does not occur on most amino acids, nor on mono-or disaccharides. Optimum growth temperature about $37^{\circ} \mathrm{C}$. Produces polyhydroxybutyrate storage granules. Neutral $\mathrm{pH}$ optimal for growth. Major cellular fatty acids are $\mathrm{C}_{16: 1} \omega 7 \mathrm{c}, \mathrm{C}_{16: 0}$ and $\mathrm{C}_{18: 1} \omega 7 \mathrm{c}$. $\mathrm{G}+\mathrm{C}$ content of DNA is $65-68 \mathrm{~mol} \%$. Type species is Azospira oryzae.

\section{Description of Azospira restricta sp. nov.}

Azospira restricta (res.tric'ta. L. fem. part. adj. restricta limited, restricted, referring to the restricted spectrum of metabolized substrates).

On VM ethanol agar colonies are 1-2 mm diameter, translucent, greenish-yellow, smooth, convex with entire margins. On R2A agar colonies are cream-coloured, smooth, convex with entire margins. Straight or curved rods, $0.5 \times$ $1.2-2.5 \mu \mathrm{m}$. Inclusion granules are observed. Growth occurs from 20 to $40{ }^{\circ} \mathrm{C}$ with optimal growth at $37^{\circ} \mathrm{C}$. Growth occurs at neutral $\mathrm{pH}$. No growth is observed in the presence of $2 \% \mathrm{NaCl}(\mathrm{w} / \mathrm{v})$. Aesculin hydrolysis, gelatin hydrolysis, $\mathrm{H}_{2} \mathrm{~S}$ production and acetoin production do not occur. Negative for $\beta$-galactosidase, arginine dihydrogenase and lysine decarboxylase. Strain SUA2 ${ }^{\mathrm{T}}$ metabolizes $\beta$-hydroxybutyrate, $\gamma$-hydroxybutyrate, D,L-lactate and putrescine as growth substrates, but does not metabolize other substrates in Biolog GN and GP microplates. Nitrate and perchlorate are not used as electron acceptors. Growth occurs on $\beta$ hydroxybutyric acid, $\gamma$-hydroxybutyric acid, D,L-lactic acid and putrescine. Dominant cellular fatty acids are $\mathrm{C}_{16: 0}$, $\mathrm{C}_{16: 1} \omega 7 \mathrm{c}, \mathrm{C}_{17: 0}$ cyclo, $\mathrm{C}_{10: 0} 3-\mathrm{OH}, \mathrm{C}_{18: 1} \omega 7 \mathrm{c}, \mathrm{C}_{12: 0}$ and $\mathrm{C}_{15: 0}$. DNA G+C content is $67.9 \mathrm{~mol} \%$.

The type strain $\quad \mathrm{SUA} 2^{\mathrm{T}} \quad\left(=\mathrm{NRRL} \quad \mathrm{B}-41660^{\mathrm{T}}=\mathrm{DSM}\right.$ $18626^{\mathrm{T}}=$ LMG $23819^{\mathrm{T}}$ ) was isolated from groundwater.

\section{Acknowledgements}

This research was funded by the Governor's Biotechnology Initiative of the Louisiana Board of Regents grant BOR\#015 (Enhancement of the LSU Hazardous Substance Research Center Environmental Biotechnology Initiative) and NPC Services, Inc. The authors thank Cindy Henk of the LSU Socolofsky Microscopy Center for assistance with microscopy. The authors thank Jean Euzéby for assistance with the etymology of the new species.

\section{References}

Achenbach, L. A., Michaelidou, U., Bruce, R. A., Fryman, J. \& Coates, J. D. (2001). Dechloromonas agitata gen. nov., sp. nov. and Dechlorosoma suillum gen. nov., sp. nov., two novel environmentally dominant (per)chlorate-reducing bacteria and their phylogenetic position. Int J Syst Evol Microbiol 51, 527-533.

Bowman, K. S., Moe, W. M., Rash, B. A., Bae, H. S. \& Rainey, F. A. (2006). Bacterial diversity of an acidic Louisiana groundwater contaminated by DNAPL containing chloroethanes and other solvents. FEMS Microbiol Ecol 58, 120-133.

Felsenstein, J. (2004). PHYLIP (phylogeny inference package), version 3.62. Distributed by the author. Department of Genome Sciences, University of Washington, Seattle, USA.

Hall, T. A. (1999). BioEdit: a user-friendly biological sequence alignment editor and analysis program for Windows 95/98/NT. Nucleic Acids Symp Ser 41, 95-98.

Jukes, T. H. \& Cantor, C. R. (1969). Evolution of protein molecules. In Mammalian Protein Metabolism, pp. 21-132. Edited by H. Munro. New York: Academic Press.

Kumar, S., Tamura, K. \& Nei, M. (2004). MEGA3: integrated software for molecular evolutionary genetics analysis and sequence alignment. Brief Bioinformat 5, 150-163.

Mesbah, M., Premachandran, U. \& Whitman, W. B. (1989). Precise measurement of the $\mathrm{G}+\mathrm{C}$ content of deoxyribonucleic acid by highperformance liquid chromatography. Int J Syst Bacteriol 39, 159-167.

Poly, F., Monrozier, L. J. \& Bally, R. (2001). Improvement in the RFLP procedure for studying the diversity of nifH genes in communities of nitrogen fixers in soil. Res Microbiol 152, 95-103.

Rainey, F. A., Ward-Rainey, N., Kroppenstedt, E. \& Stackebrandt, E. (1996). The genus Nocardiopsis represents a phylogenetically 
coherent taxon and a distinct actinomycete lineage: proposal of Nocardiopsaceae fam. nov. Int J Syst Bacteriol 46, 1088-1092.

Reinhold, B., Hurek, T., Niemann, E.-G. \& Fendrik, I. (1986). Close association of Azospirillum and diazotrophic rods with different root zones of Kallar grass. Appl Environ Microbiol 52, 520-526.

Reinhold-Hurek, B. \& Hurek, T. (2000). Reassessment of the taxonomic structure of the diazotrophic genus Azoarcus sensu lato and description of three new genera and new species, Azovibrio restrictus gen. nov., sp. nov., Azospira oryzae gen. nov., sp. nov. and Azonexus fungiphilus gen. nov., sp. nov. Int J Syst Evol Microbiol 50, 649-659.

Reinhold-Hurek, B., Hurek, T., Gillis, M., Hoste, B., Vancanneyt, M., Kersters, K. \& De Ley, J. (1993). Azoarcus gen. nov., nitrogen-fixing proteobacteria associated with roots of Kallar grass (Leptochlora fusca (L.) Kunth), and description of two species, Azoarcus indigens sp.nov. and Azoarcus communis sp. nov. Int J Syst Evol Microbiol 43, 574-584.

Sasser, M. (1990). Identification of Bacteria by Gas Chromatography of Cellular Fatty Acids. MIDI Technical Note 101. Newark, DE: MIDI Inc.
Simpson, J. M., Santo Domingo, J. W. \& Reasoner, D. J. (2004). Assessment of equine fecal contamination: the search for alternative bacterial source-tracking targets. FEMS Microbiol Ecol 47, 65-75.

Smibert, R. M. \& Krieg, N. R. (1981). General characterization. In Manual of Methods for General Bacteriology, pp. 409-443. Edited by P. Gerhardt, R. G. E. Murray, R. N. Costilow, E. W. Nester, W. A. Wood, N. R. Krieg \& G. B. Phillips. Washington, DC: American Society for Microbiology.

Tan, Z. \& Reinhold-Hurek, B. (2003). Dechlorosoma suillum Achenbach et al. 2001 is a later subjective synonym of Azospira oryzae Reinhold-Hurek and Hurek 2000. Int J Syst Evol Microbiol 53, 1139-1142.

Tarrand, J. J. \& Gröschel, D. H. M. (1982). Rapid, modified oxidase test for oxidase-variable bacterial isolates. J Clin Microbiol 16, $772-774$.

Thompson, J. D., Gibson, T. J., Plewniak, F., Jeanmougin, F. \& Higgins, D. G. (1997). The CLUSTAL_X windows interface: flexible strategies for multiple sequence alignment aided by quality analysis tools. Nucleic Acids Res 25, 4876-4882. 